\title{
EVALUATION OF ECONOMIC THRESHOLD LEVEL OF THE SEY- CHELLES FLUTED SCALE, ICERYA SEYCHELLARUM (WESTWOOD) (HEMIPTERA: MONOPHLEBIDAE) ON MANGO TREES IN GIZA GOVERNORATE
}

\author{
SERAG, A. M. \\ Plant Protection Research Institute, ARC, Dokki, Giza, Egypt. \\ (Manuscript received 26 February 2017)

\begin{abstract}
$\mathrm{T}$ he seychelles fluted scale, Icerya seychellarum (Westwood) (Monophlebidae: Hemiptera) is a serious pest of mango in Egypt, while it causes yield loss in most of mango orchards all over the country. The economic threshold level is a key factor to start control program. Results of statistical analysis shown that, when population density of $I$. seychellarum were (27.24 \& 27.22) pre-adult / leaf) in March and June infestation, respectively. These numbers could be regarded as economic threshold of infestation with $I$. seychellarum on mango trees, at this level sufficient time for initiation of control measures. Population of $I$. seychellarum showed four annual generations and four activity peaks; a small peak in mid-March, intermediate peak in June, the third peak in August and last peak in mid-September.

Key words: Icerya seychellarum, Economic Level, Mangifera indica.
\end{abstract}

\section{INTRODUCTION}

Mango, Mangifera indica (L.) (Anacardiaceae) is one of the most popular and economic fruit trees pests in Egypt, according to the latest survey of Egyptian Ministry of Agriculture in 2016. Mango orchards occupy 281.153 feddan and considered the third important fruit crop after grapes and citrus (Economic affairs Sector, 2016). Mango trees are liable to be infested with several serious insect pests during their growth stages including the seychelles fluted scale, I. seychellarum (Elwan, 1990). At high infestation levels, serious damage resulted in early leaf drop and yield reduction is caused by the feeding of this insect, but the major damage is caused by the production of large amounts of honeydew upon which saprophytic fungi is develop, which interferes with photosynthesis and respiration (Assem, 1990) and otherwise reduces the quality of the plant causing considerable economic injury. Moreover, high populations of $I$. seychellarum can reduce the vigor of the plant, making it susceptible to other pests (Osman, 2005). The economic threshold is fundamental integrated pest management (IPM) concepts. Also, decisions about control measures should be based upon the economic threshold

level, i.e., that population density at which control measures are necessary to prevent 
eventual economic damage. The present work aims to evaluate of the economic threshold level of infestation with the seychelles fluted scale, I. seychellarum on mango trees in Giza Governorate.

\section{MATERIALS AND METHODS}

To estimate the economic threshold level of infestation with I. schychellarum to mango trees, mango orchard located at El-Saff, Giza Governorate $75 \mathrm{Km}$. south of Cairo was chosen for these purposes. The mango trees, Mangifera indica cv. sultani about 8-9 years old. These trees were received the same agricultural practices during the experimental period. From these trees twenty five trees of the same age, shape, size, vegetative growth and infest with $I$. seychellarum were selected for experimental purposes. The selected trees received no insecticidal application during experiment period. In order to determine the population density of the seychelles fluted scale, $I$. seychellarum on the selected trees, half-monthly samples each consisted of 20 leaves were picked at random of each tree from January to December, 2015. These samples were kept in special plastic boxes and transferred to laboratory for counting procedures by aid of stereoscopic microscope. This involved estimation of the average number of alive pre-adult and adult females per 20 leaves. To estimate the population density of this species, the selected trees were enumerated and mean number of alive pre-adults / leaves were recorded half-monthly intervals from the beginning of January to end of July, 2016 and the average of individuals were calculated for each tree. During the harvest season on August, 2016 total mango fruit yield of each tree was weighted and fruit yield Kgs. /tree was recorded. To estimate the economic threshold level of infestation due to infestation by $I$. seychellarum, it was found more convenient to use average number of pre-adults / leaves for each tree throughout March \& June infestation as independent factor ( $x 1 \& x 2)$, respectively. While, mango fruit weight in Kgs. /tree was used as dependent factor ( $y$ ). When correlation coefficient value was significant regression coefficient (b) value was calculated using this formula according to (SAS Institute, 1989).

$$
\grave{y}=a \pm b x
$$

Where:

$$
\begin{aligned}
& \text { ỳ : Expected value } \\
& a: \text { Constant } \\
& \text { b : Regression coefficient } \\
& x \text { : Mean number of pre-adult / tree }
\end{aligned}
$$


This value was calculated at this stage to determine the slope of straight regression line. But since the yield population relationship found to be more or less curved than linear thus a curved regression line had to be fitted. The obtained values of (y) for each tree were arranged in descending order, while average numbers of pre-adults / leaves for each tree were arranged in ascending order. To achieve the point which the weight started to show a significant drop in the yield, the method of Chi-square

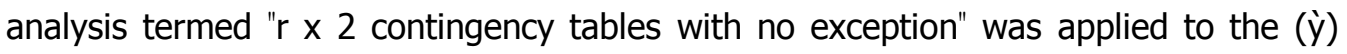
data. The following model elucidates this procedure according to (SAS Institute, 1989):

$$
\chi^{2}=\Sigma(n i-e i)^{2}
$$

ei

Where:

$$
\begin{aligned}
& \chi^{2} \text { : Chi-square. } \\
& \text { ni : Observed yield. } \\
& \text { ei : Expected yield. }
\end{aligned}
$$

The statistical analysis of data was carried out with computer (SAS Institute).

\section{RESULTS AND DISCUSSION}

Data on the half-monthly counts of $I$. schychellarum on mango trees during, 2015 were shown in Table (1) and illustrated in Fig. (1), it shown that the seychelles fluted scale recorded 4 annual generations per year, the first peak was in mid-March and the second one was in June, the third one in August and the fourth one in mid-September. The mango fruit yield of variety (sultani) was harvested during August. This means that the first generation started from mid-February to end of April and peaked in midMarch and the second generation started in April to July and peaked in June is effective on mango yield. So, the present work, data of insect counts during the first and second peaks of abundance were analyzed statistically and correlated with the yield of mango fruits. 

ICERYA SEYCHELLARUM (WESTWOOD) (HEMIPTERA: MONOPHLEBIDAE)

ON MANGO TREES IN GIZA GOVERNORATE

Table 1 . Half-monthly counts of $I$. schychellarum represented by means of alive individuals on 20 leaves of mango at El Saff, Giza Governorate from January to December, 2015.

\begin{tabular}{|l|l|l|l|}
\hline \multicolumn{1}{|c|}{ Sampling dates } & Pre-adults & Adults & Population \\
\hline 01-Jan., 2015 & 16.20 & 10.30 & 26.50 \\
\hline 15-Jan., 2015 & 16.70 & 11.20 & 27.90 \\
\hline 01-Feb., 2015 & 13.10 & 10.70 & 23.80 \\
\hline 15-Feb., 2015 & 10.50 & 9.50 & 20.00 \\
\hline 01-Mar., 2015 & 20.00 & 10.40 & 30.40 \\
\hline 15-Mar., 2015 & 26.30 & 14.00 & 40.30 \\
\hline 01-Apr., 2015 & 12.20 & 9.90 & 22.10 \\
\hline 15-Apr., 2015 & 17.60 & 12.70 & 30.30 \\
\hline 01-May, 2015 & 36.30 & 19.40 & 55.70 \\
\hline 15-May, 2015 & 53.60 & 23.30 & 76.90 \\
\hline 01-Jun., 2015 & 64.20 & 18.80 & 83.00 \\
\hline 15-Jun., 2015 & 55.70 & 15.10 & 70.80 \\
\hline 01-Jul., 2015 & 31.90 & 13.80 & 45.70 \\
\hline 15-Jul., 2015 & 51.40 & 19.30 & 70.70 \\
\hline 01-Aug., 2015 & 124.10 & 41.20 & 165.30 \\
\hline 15-Aug., 2015 & 53.60 & 28.30 & 81.90 \\
\hline 01-Sep., 2015 & 111.60 & 34.70 & 146.30 \\
\hline 15-Sep., 2015 & 130.40 & 50.00 & 180.40 \\
\hline 01-Oct., 2015 & 81.50 & 28.40 & 109.90 \\
\hline 15-Oct., 2015 & 59.70 & 22.20 & 81.90 \\
\hline 01-Nov., 2015 & 39.10 & 21.20 & 60.30 \\
\hline 15-Nov., 2015 & 20.00 & 49.40 & 42.70 \\
\hline 01-Dec., 2015 & 23.90 & & \\
\hline 15-Dec., 2015 & 23.30 & 20.90 \\
\hline
\end{tabular}




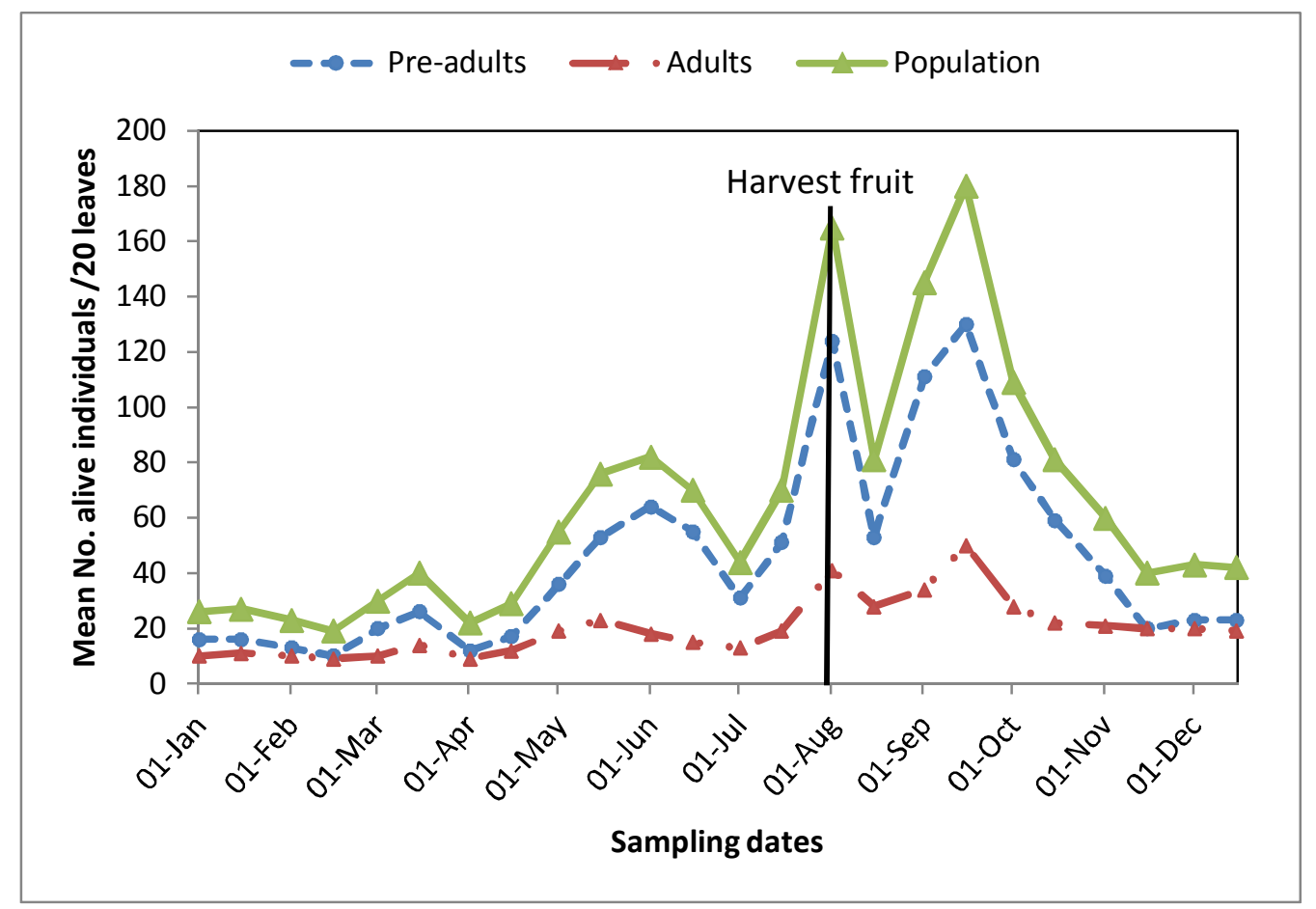

Fig.1. Half-monthly fluctuation of $I$. seychellarum on mango trees under field conditions in Giza Governorate, 2015.

\section{Effect of mean number of pre-adult on mango fruit yield}

Results obtained and statistical analysis are given in Table (2) and graphically illustrated in Fig. (2) showed that the relationship between mean number of preadults / leaf in March and June generations and mango fruit yield were negative and very highly significant. The correlation coefficient value in March and June generations were $(-0.9746 \&-0.9412)$, respectively. Also, a regression coefficient value were $(-2.1324 \&-1.9076)$, respectively. Thus means that when population density of the seychelles fluted scale increased mango fruit yield was decreased. 

ICERYA SEYCHELLARUM (WESTWOOD) (HEMIPTERA: MONOPHLEBIDAE)

ON MANGO TREES IN GIZA GOVERNORATE

Table 2. Relationship between different levels of mean numbers of pre-adults of $I$. schychellarum throughout activity period and mango fruit yield of 25 mango trees in Giza Governorate during, 2016.

\begin{tabular}{|c|c|c|c|}
\hline \multirow{2}{*}{ Tree No. } & \multirow{2}{*}{$\begin{array}{c}\text { Yield in Kg. / } \\
\text { tree }\end{array}$} & \multicolumn{2}{|c|}{ Average number of pre-adults / leaf } \\
\hline & & March & June \\
\hline 1 & 45.93 & 21.74 & 22.92 \\
\hline 2 & 28.43 & 30.14 & 30.22 \\
\hline 3 & 39.13 & 24.84 & 24.32 \\
\hline 4 & 13.93 & 36.14 & 36.42 \\
\hline 5 & 28.23 & 30.24 & 31.12 \\
\hline 6 & 29.93 & 29.04 & 28.92 \\
\hline 7 & 33.73 & 27.24 & 27.22 \\
\hline 8 & 47.13 & 21.64 & 18.92 \\
\hline 9 & 41.63 & 23.74 & 23.02 \\
\hline 10 & 9.73 & 38.34 & 39.12 \\
\hline 11 & 12.23 & 36.94 & 35.12 \\
\hline 12 & 26.93 & 30.24 & 28.52 \\
\hline 13 & 24.13 & 31.64 & 31.82 \\
\hline 14 & 19.23 & 33.74 & 33.52 \\
\hline 15 & 27.13 & 29.94 & 30.02 \\
\hline 16 & 21.93 & 32.54 & 32.52 \\
\hline 17 & 27.03 & 28.24 & 29.42 \\
\hline 18 & 21.93 & 32.44 & 32.72 \\
\hline 19 & 31.53 & 28.24 & 30.82 \\
\hline 20 & 11.93 & 36.94 & 38.32 \\
\hline 21 & 15.13 & 35.64 & 36.22 \\
\hline 22 & 26.43 & 26.04 & 25.42 \\
\hline 23 & 29.93 & 29.84 & 32.72 \\
\hline 24 & 22.13 & 32.44 & 32.82 \\
\hline 25 & 27.63 & 29.94 & 30.02 \\
\hline \multicolumn{2}{|c|}{ Simple correlation (r) } & -0.9746 & -0.9412 \\
\hline \multicolumn{2}{|c|}{ Simple regression (b) } & -2.1324 & -1.9076 \\
\hline
\end{tabular}

From the aforementioned results, it could be stated that population density of $I$. schychellarum during main period of activity found to be greatly affected on fruits yield. The injury caused by this pest found to cause great damages to mango fruit yield. 


\section{Estimation of economic threshold level of infestation}

Result of statistical analysis showed that population density of this pest was highly significant correlated with fruit yield. Therefore, losses assessment must be depend on mango fruit yield losses. Estimation of "Economic Levels of Infestation" will be based on correlation different levels of population density of I. schychellarum and mango fruit yield per tree in order to take correct decision for control measures. In found more convenience to illustrate definition of some terms about "Economic Threshold Level of Infestation" according Pedigo et al. (1986) and Pedigo and Higley (1992). To achieve this, the method of Chi-square termed " $r$ x 2 contingency tables" was applied to determine (yे) data. Results of statistical analysis are given in Table (3) and graphically illustrated in Fig. (2).

Table 3. Chi square analysis of mango yield with different levels of average number of pre-adults of $I$. seychellarum on mango trees in Giza Governorate during, 2016.

\begin{tabular}{|c|c|c|c|c|c|c|c|}
\hline \multicolumn{4}{|c|}{ March infestation (x1) } & \multicolumn{4}{|c|}{ June infestation (x2) } \\
\hline $\begin{array}{c}\text { Average } \\
\text { No. of pre- } \\
\text { adults / } \\
\text { leaf }\end{array}$ & $\begin{array}{c}\text { observed } \\
\text { yield } \\
\text { (Kg.) }\end{array}$ & $\begin{array}{c}\text { Expected } \\
\text { Yield } \\
\text { (Kg.) }\end{array}$ & $\chi^{2}$ & $\begin{array}{c}\text { Average } \\
\text { No. of pre- } \\
\text { adults / } \\
\text { leaf }\end{array}$ & $\begin{array}{c}\text { observed } \\
\text { yield } \\
\text { (Kg.) }\end{array}$ & $\begin{array}{c}\text { Expected } \\
\text { Yield } \\
\text { (Kg.) }\end{array}$ & $\chi^{2}$ \\
\hline 21.64 & 47.13 & 48.77 & 1.3787 & 18.92 & 47.13 & 48.31 & 0.7206 \\
\hline 21.74 & 45.93 & 47.57 & 1.4135 & 22.92 & 45.93 & 47.11 & 0.7389 \\
\hline 23.74 & 41.63 & 43.27 & 1.5540 & 23.02 & 41.63 & 42.81 & 0.8131 \\
\hline 24.84 & 39.13 & 40.77 & 1.6493 & 24.32 & 39.13 & 40.31 & 0.8636 \\
\hline 26.04 & 33.73 & 35.37 & 1.9010 & 25.42 & 33.73 & 34.91 & 0.9971 \\
\hline 27.24 & 31.53 & 33.17 & 2.0271 & 27.22 & 31.53 & 32.71 & 1.0642 \\
\hline 28.24 & 29.93 & 31.57 & 2.1299 & 28.52 & 29.93 & 31.11 & 1.1189 \\
\hline 28.24 & 29.93 & 31.57 & 2.1299 & 28.92 & 29.93 & 31.11 & 1.1189 \\
\hline 29.04 & 28.43 & 30.07 & 2.2361 & 29.42 & 28.43 & 29.61 & 1.1756 \\
\hline 29.84 & 28.23 & 29.87 & 2.2511 & 30.02 & 28.23 & 29.41 & 1.1836 \\
\hline 29.94 & 27.63 & 29.27 & 2.2972 & 30.02 & 27.63 & 28.81 & 1.2083 \\
\hline 29.94 & 27.13 & 28.77 & 2.3372 & 30.22 & 27.13 & 28.31 & 1.2296 \\
\hline 30.14 & 27.03 & 28.67 & 2.3453 & 30.82 & 27.03 & 28.21 & 1.2340 \\
\hline 30.24 & 26.93 & 28.57 & 2.3535 & 31.12 & 26.93 & 28.11 & 1.2383 \\
\hline 30.24 & 26.43 & 28.07 & 2.3954 & 31.82 & 26.43 & 27.61 & 1.2608 \\
\hline 31.64 & 24.13 & 25.77 & 2.6092 & 32.52 & 24.13 & 25.31 & 1.3753 \\
\hline 32.44 & 22.13 & 23.77 & 2.8288 & 32.72 & 22.13 & 23.31 & 1.4934 \\
\hline 32.44 & 21.93 & 23.57 & 2.8528 & 32.72 & 21.93 & 23.11 & 1.5063 \\
\hline 32.54 & 21.93 & 23.57 & 2.8528 & 32.82 & 21.93 & 23.11 & 1.5063 \\
\hline 33.74 & 19.23 & 20.87 & 3.2218 & 33.52 & 19.23 & 20.41 & 1.7055 \\
\hline 35.64 & 15.13 & 16.77 & 4.0095 & 35.12 & 15.13 & 16.31 & 2.1343 \\
\hline 36.14 & 13.93 & 15.57 & 4.3186 & 36.22 & 13.93 & 15.11 & 2.3038 \\
\hline 36.94 & 12.23 & 13.87 & 4.8479 & 36.42 & 12.23 & 13.41 & 2.5958 \\
\hline 36.94 & 11.93 & 13.57 & 4.9550 & 38.32 & 11.93 & 13.11 & 2.6552 \\
\hline 38.34 & 9.73 & 11.37 & 5.9138 & 39.12 & 9.73 & 10.91 & 3.1907 \\
\hline
\end{tabular}



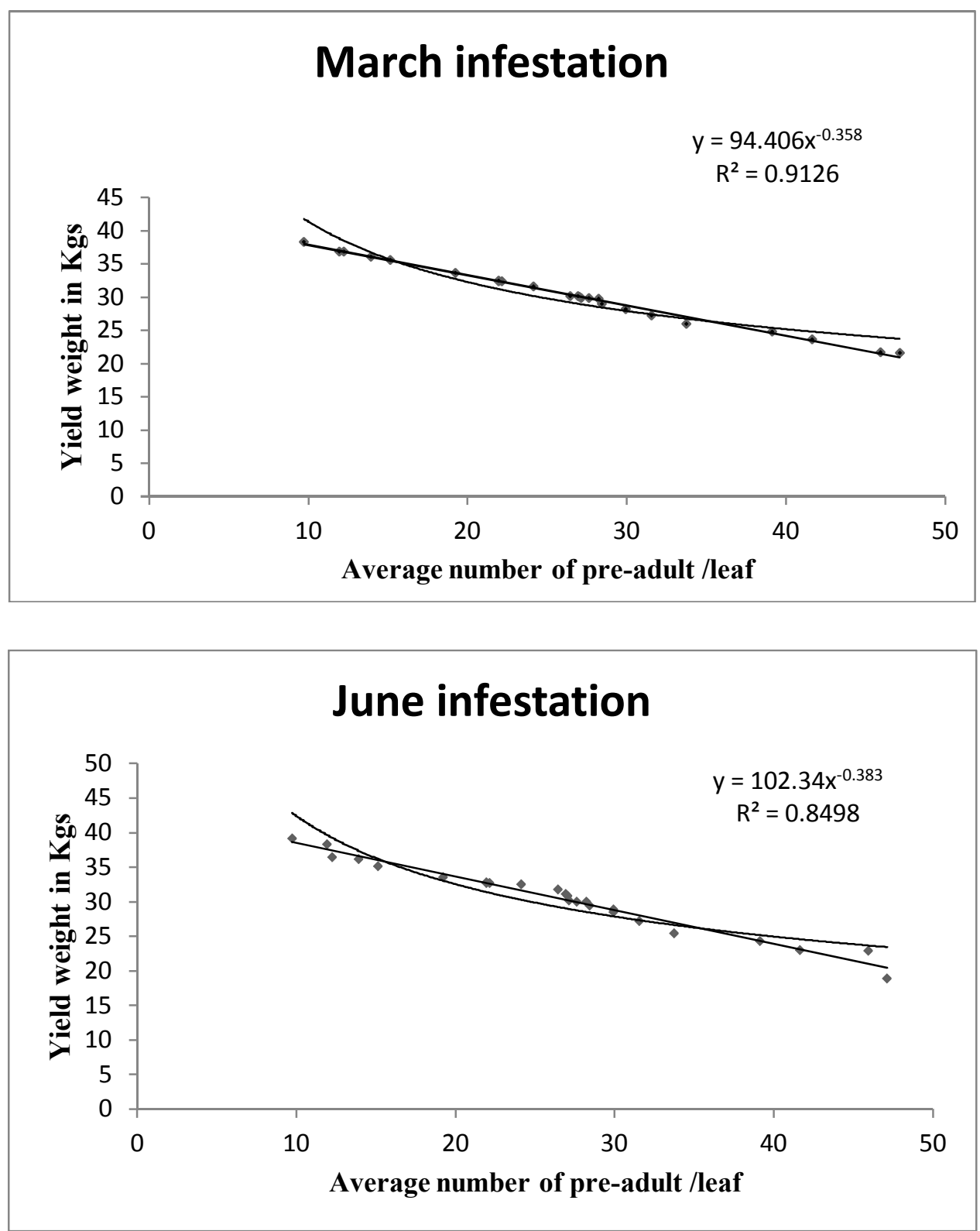

Fig. 2. The corrected average change in mango fruit yield / unit (ỳ) change with I. seychellarum infestation in March and June infestation ( $x 1 \& \times 2)$ during, 2016, on mango trees in Giza Governorate.

For the part of the population density of $I$. seychellarum during March period of seasonal activity ranging between ( 0.0 to 26.04 ) alive pre-adult / leaf, the chi-square value for the yield (1.901) was insignificant, denoting that the corresponding reduction in the yield could be due to chance only. However, for figures from (27.24) alive preadults / leaf and up, the chi-square value (2.027) indicated a significant drop in the yield. Thus, the increase of insect number to an average of 27.24 / leaf could be regarded as the economic threshold for the March infestation. 
For June period the increase of infestation from ( 0.0 to 25.42$)$ alive pre-adult / leaf decreased the mango yield insignificantly. At the range from (27.22) alive preadults /leaf and up, there was a significant decrease in the yield, Chi-square value was (1.0642). Therefore, (27.24 \& 27.22) pre-adult / leaf could be regarded as economic threshold of March \& June infestation with $I$. seychellarum on mango trees under weather conditions of Giza Governorate, respectively.

These results are related to those obtained by (Abd El-Rahman et al.,2007) recorded combined numbers of individuals (pre-adults and adult females) on mango leaves indicated that activity of $I$. seychellarum extended from March to November with a small activity peak on mid-March, peak of intermediate population density during June and two approximately equal large peaks on August and mid-September (Salem et al., 2006) found that susceptibility of five mango cultivars to infestation with I. seychellarum that sultani variety is the most susceptible to infestation (Selim and Badary, 2013) stated that the economic threshold for Lepidosaphes pallida on mango trees 3.1 adult females / leaf in April infestation while, 10.1 adult female/leaf in July infestation.(Hosny et al., 1972) determined the economic damage threshold for the different infestation densities of $A$. aurantii (Maskell) on mandarin trees. He found that more than $0.24,0.18$ adult females / leaf during June and October respectively decreased the yield of fruit significantly.

\section{REFERENCES}

1. Abd El-Rahman, M.M.; M.S. Salem; S.F.M.Moussa; M.E. Nour and Maha, I. El Said 2007. Seasonal fluctuation of the seychelles fluted scale, $I$. seychellarum (Westwood) on four mango cultivars in Egypt. Egypt. J. Agric. Res., 85 (1) 77.

2. Assem, M.S. 1990. Survey and Biological Studies on Some Insects Attacking Certain Ornamental Plants. Ph.D. Thesis, Fac. Agric., Cairo Univ., Cairo, Egypt. 202 p.

3. Elwan, E.A. 1990. Ecological and Biological Studies on Certain Insect Pests of Coccoidea (Hemiptera) Infecting Mango trees. Ph.D. Thesis, Fac. Agric. Al-Azhar Univ., Cairo, Egypt. 200 p.

4. Economic Affair Sector for Statistics, Bull. Agr. Statistics, part (2), September, 2016

5. Hosny, M. M.; A.H. Amin and G.B. El-Saadany. 1972. The damage threshold of the red scale, Aonidiella aurantii (Maskell) infesting mandarin trees in Egypt. Z. ang. Ent., 71: 286-296. 
6. Osman, E.A. 2005. Studies on some Homoptera insect pests infesting mulberry trees in relation with Bombxmori L. Silk production. Ph.D Thesis, Fac. Agric., Cairo Univ. Egypt.

7. Pedigo, L.P.; S.H. Hutchins and L.G. Higley. 1986. Economic injury levels in theory and practice. Ann. Rev. Entom. $31:$ 341-368.

8. Pedigo, K. P., and L. G. Higley. 1992: The economic injury level concept environmental quality: a new perspective. American Entomologist 38:12-21.

9. Selim, A. and Badary, H. 2013. Assessment of economic threshold and economic injury levels of the Maskell scale insect, Lepidosaphes pallida on mango trees. Egypt. J. Agric. Res., 91(3): 203-212.

10. Salem, M.S.; Maha, I. El- Said; A.M. Abd El-Ghany and M.M. Abd El-Rahman. 2006. Susceptibility of five mango cultivars to $I$. seychellarum (Westwood) (Homoptera: Margarodidae) in relation to leaf quality, nutrients and inhibitors. Egypt. J. Agric. Res., 84 (83):697.

11. SAS Institute Inc. 1989. Version 6, First Edition, Volume 1, Cary, NC. 


\title{
تقدير الحد الأقتصادى الحرج لحشرة بق السيشيلارم الدقيقى على أشجار المانجو فى محافظة الجيزة
}

\author{
عادل محمد سراج \\ معهز بحوث وقاية النباتات - مركز البحوث الزراعية - الدقى - الجيزة - مصر
}

تعتبر حشرة بق السيشيلارم الدقيقى من الآفات الخطيرة التى تصيب أثنجار المـانجو ، حيــث

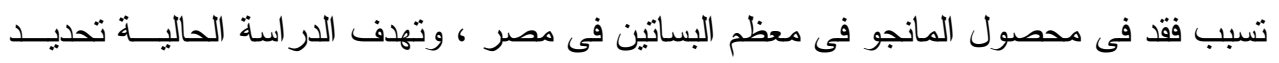

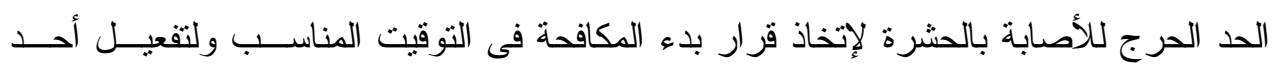

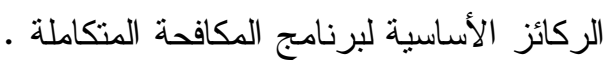

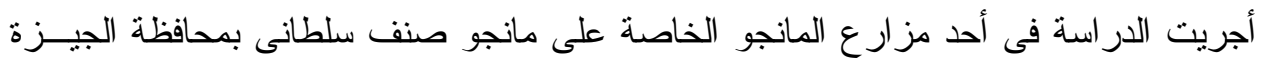
خلال عامى 2016 \& 2015 .

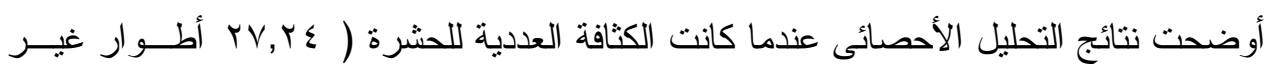

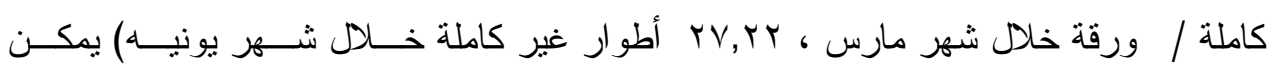

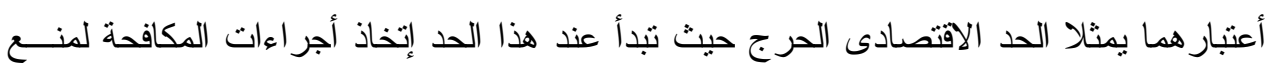

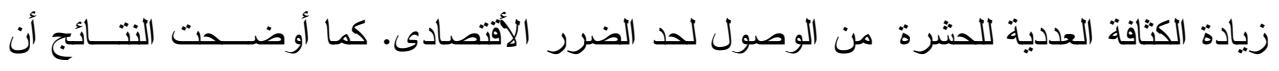

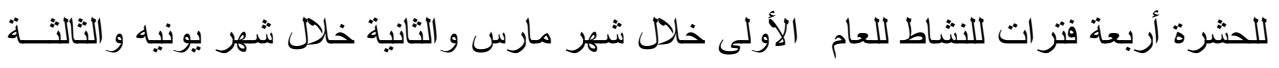

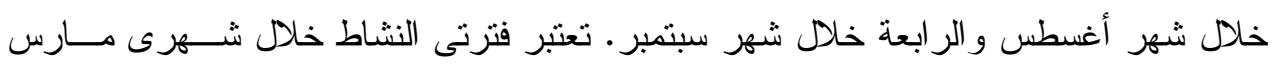

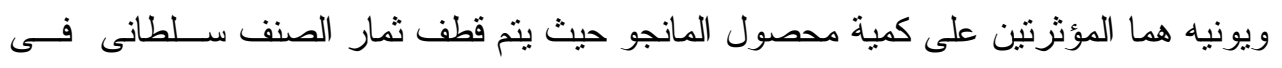
بداية شهر أغسطس قبل بداية الجيل الثالث. 